\title{
PENGARUH SKEPTISME PROFESIONAL, PENGALAMAN KERJA, DAN TIME \\ BUDGET PRESSURE TERHADAP KUALITAS AUDIT (STUDI EMPIRIS PADA \\ KANTOR AKUNTAN PUBLIK DI JAKARTA SELATAN)
}

\author{
Nia Tresnawaty, SE.,M.Ak \\ dan \\ Putra Kurniansyah
}

\begin{abstract}
Fakultas Ekonomi, Universitas Satya Negara Indonesia, Jakarta
E-mail : niatresna@yahoo.com

E-mail :putrakurniansyah@ymail.com
\end{abstract}

\begin{abstract}
This study aims to obtain empirical evidence of the influence of Professional Skepticism, Work Experience, and Time Budget Pressure on Audit Quality. This research was conducted at Auditor Public Accounting Firm in South Jakarta. The number of samples used are 104 auditors from 12 Public Accounting Firm. The indicators used are 19 indicators. Sampling method using Purposive Sampling method, the analysis technique used is multiple linear analysis technique previously tested the validity, reliability, and test of classical assumptions.

The results show that professional skepticism and work experience have a positive and significant impact on Audit Quality at Public Accountant Office in South Jakarta, while Time Budget Pressure has no significant effect on Quality in Public Accountant Audit in South Jakarta.
\end{abstract}

Key words: Professional Skepticim, work experience, Time Budget Pressure, Quality Audit 


\begin{abstract}
ABSTRAK
Penelitian ini bertujuan untuk memperoleh bukti empiris pengaruh Skeptisme Professional, Pengalaman Kerja, dan Time Budget Pressure terhadap Kualitas Audit. Penelitian ini dilakukan pada auditor Kantor Akuntan Publik di Jakarta Selatan. Jumlah sampel yang digunakan sebanyak 104 auditor dari 12 Kantor Akuntan Publik. Indikator yang digunakan sebanyak 19 indikator. Metode pengambilan sampel dengan menggunakan metode Purposive Sampling, teknik analisis yang digunakan adalah teknik analisis linier berganda yang sebelumnya dilakukan uji validitas, reabilitas, dan uji asumsi klasik.

Hasil penelitian membuktikan bahwa Skeptisme profesional dan Pengalaman Kerja berpengaruh positif dan siginifikan terhadap Kualitas Audit pada Kantor Akuntan Publik di Jakarta Selatan, sedangkan Time Budget Pressure tidak berpengaruh signifikan terhadap Kualitas pada Audit Kantor Akuntan Publik di Jakarta Selatan
\end{abstract}

Kata Kunci: Skeptisme Professional, Pengalaman Kerja, Time Budget Pressure, Kualitas Audit 


\section{PENDAHULUAN}

Laporan keuangan suatu perusahaan pada dasarnya harus mempunyai tata kelola yang baik dan bertanggungjawab karena laporan keuangan merupakan gambaran dari kinerja suatu perusahaan untuk memberikan informasi kepada pemangku kepentingan, sehingga diperlukan jasa audit untuk mengukur keandalan dari laporan keuangan tersebut. Menurut Boyton et al. (2006:7) dalam Komang dkk (2016) kualitas jasa sangat penting untuk menghasilkan bahwa profesi bertanggung jawab kepada klien, masyarakat umum dan aturanaturannya. Untuk meningkatkan kepercayaan para pengguna laporan keuangan serta menjaga eksistensi dalam persaingan antar akuntan publik, sebuah akuntan publik harus memperhatikan kualitas audit yang dihasilkannya (Ahmad dkk, 2011)

Tingkat kepercayaan masyarakat akan kualitas audit pada masa sekarang ini mengalami penurunan karena terdapat beberapa kasus yang masih terdapat kecurangan dalam laporan keuangan perusahaan dan publik bertanya apakah kantor akuntan publik telah melaksanakan audit dengan baik sesuai dengan standarnya atau belum. Jika kantor audit telah melaksanakan proses audit yang baik maka akan menghasilkan audit yang berkualitas. Kualitas audit menjadi penting karena dapat berpengaruh pada citra Kantor Akuntan Publik tersebut baik bagi klien maupun bagi masyarakat. Salah satu Kasus yang menimpa Toshiba tahun 2015 merupakan salah satu Contoh perusahaan yang melakukan manipulasi laporan keuangan yang melibatkan auditor dalam kecurangan tersebut sehingga menyebabkan laporan keuangan tersebut tidak berkualitas. KAP yang mengaudit laporan keuangan Toshiba yaitu Ernst \& Young (EY). EY telah bekerja sama melakukan audit untuk Toshiba selama 12 tahun terhitung sejak tahun 2002 hingga 2014 tidak mampu menemukan serta melaporkan kalau perusahaan ini ternyata melakukan kecurangan. Atas kejadian tersebut, regulator keuangan Jepang akan mendenda perusahaan afiliasi Ernst \& Young sebesar 2,1 miliaryen (US\$17,4 juta) setelah lembaga tersebut gagal melihat penyimpangan standar akuntansi di Toshiba serta akan menangguhkan Ernest \& Young dalam mengambil kontrak bisnis baru selama tiga bulan (Kompas.com, 2016).

Adanya fenomena tersebut menggambarkan masih banyak laporan keuangan yang tidak berkualitas. Walaupun menggunakan jasa auditor eksternal akan tetapi auditor tersebut tidak mampu mengungkapkan sehingga menyebabkan menurunnya kualitas audit

De Angelo (1981) dalam Ningsih dan Dyan (2013) mendefinisikan kualitas audit sebagai suatu kondisi dimana auditor akan menemukan dan melaporkan pelanggaran dalam sistem akuntansi klien. Bagi akuntan publik kepercayaan klien dan pemakai laporan keuangan eksternal atas kualitas audit dan jasa lainnya sangatlah penting. Jika para pemakai jasa tidak memiliki kepercayaan kepada akuntan publik maka kemampuan para profesional itu untuk melayani klien serta masyarakat secara efektif akan hilang (Iriyadi dan Vannywati, 2011).

Kualitas audit dapat diperoleh dari beberapa faktor yaitu diantaranya sikap Skeptisme Profesional seorang auditor. Secara khusus dalam audit, Standar Profesional Akuntan Publik (IAPI, 2011) menjelaskan bahwa skeptisme profesional adalah sikap yang selalu mempertanyakan dan melakukan evaluasi bukti audit secara kritis. Skeptisme profesional merupakan suatu perilaku pemikiran yang secara kritis atas bahan bukti audit. Auditor tidak harus menganggap bahwa manajemen telah berlaku tidak jujur, namun kemungkinan bahwa adanya ketidakjujuran harus dipertimbangkan. Pada saat yang sama, auditor juga harus menganggap bahwa manajemen telah berlaku jujur. (Arens, 2011). 
Dalam penelitian yang dilakukan oleh Ananda (2014) skeptisme profesional berpengaruh positif pada kualitas audit berbeda dengan hasil penelitian dari Nandari dan Latrini (2015) menunjukan bahwa skeptisme profesional auditor tidak berpengaruh signifikan terhadap kualitas audit.

Menurut Libby dan Frederick (1990) dalam Hanjani dan Rahardja (2014:14) pengalaman yang dimiliki auditor akan mempengaruhi kualitas auditnya, mereka menemukan bahwa semakin banyak pengalaman auditor semakin dapat menghasilkan berbagai dugaan dalam menjelaskan temuan audit. Dalam melaksanakan audit, auditor harus bertindak sebagai seorang ahli di bidang akuntansi dan auditing. Pencapaian keahlian dimulai dengan pendidikan formal, yang selanjutnya diperluas melalui pengalaman dan praktek audit (SPAP, 2011). Sesuai dengan standar umum dalam Standar Profesional Akuntan Publik bahwa auditor disyaratkan memiliki pengalaman kerja yang cukup dalam profesi yang ditekuninya, serta dituntut untuk memenuhi kualifikasi teknis dan berpengalaman dalam industri-industri yang mereka audit (Arens et al., 2011).

Untuk penelitian yang dilakukan oleh Panggih (2015), menemukan hasil variabel pengalaman auditor berpengaruh signifikan pada kualitas audit. Akan tetapi berbeda dengan Penelitian Badjuri (2011) yang menyatakan bahwa pengalaman kerja tidak berpengaruh terhadap kualitas audit.

Kualitas audit juga dipengaruhi oleh Time budget pressure. Time budget pressure menyebabkan stress individual yang timbul karena tidak seimbangnya waktu yang tersedia untuk mengerjakan tugas dan banyaknya tugas yang diberikan. Time budget pressure juga menjadi faktor yang tak kalah penting mempengaruhi kualitas audit. Bekerja dalam kondisi yang tertekan (dalam waktu) membuat auditor cenderung berperilaku disfungsional. Auditor tidak hanya dituntut untuk bekerja secara profesional, tetapi juga harus menyelesaikan tugas pengawasannya sesuai dengan anggaran waktu yang telah ditetapkan (Pangestika et al., 2014). Dezoort (1998) dalam Hutabarat (2012) menyatakan bahwa adalah hal yang umum ditemukan bahwa di bawah tekanan anggaran waktu, individu cenderung akan bekerja dengan cepat sehingga akan berdampak pada penurunan kinerjanya.

Penelitian terdahulu yang dilakukan oleh Prasita (2007) menyatakan bahwa anggaran waktu memiliki pengaruh secara negatif dan juga signifikan pada kualitas audit. Hasil yang didapat sejalan dengan penelitian yang dilakukan Ningsih (2013). Penelitian tersebut menyatakan bahwa semakin tinggi atau sempit time budget pressure yang diberikan klien kepada auditor, dapat menyebabkan menurunnya kualitas audit yang akan dihasilkan. Penelitian yang mendapatkan hasil yang berbeda dilakukan Jelista (2015) dan Arisinta (2013) yang mendapatkan hasil jika time budget pressure memiliki pengaruh positif dan juga signifikan pada kualitas audit. Penelitian tersebut menyatakan apabila semakin sempit time budget pressure yang diberikan klien kepada auditor dalam menyelesaikan tugas audit maka berdampak pada tingginya kualitas audit yang dihasilkan. 


\section{LANDASAN TEORI}

\section{Skeptisme Profesional}

Penggunaan kemahiran profesional dengan cermat dan seksama menuntut auditor untuk melaksanakan skeptisme profesional. Skeptisme profesional adalah sikap yang mencakup pikiran yang selalu mempertanyakan dan melakukan evaluasi secara kritis bukti audit. Auditor menggunakan pengetahuan, keterampilan, dan kemampuan yang dituntut oleh profesi akuntan publik untuk melaksanakan dengan cermat dan seksama, dengan maksud baik dan integritas, pengumpulan dan penilaian bukti audit secara objektif. Pengumpulan dan penilaian bukti audit secara objektif menurut auditor mempertimbangkan kompetensi dan kecukupan bukti karena bukti dikumpulkan dan dinilai selama proses audit, sehingga skeptisme profesional harus digunakan selama proses tersebut (IAPI,2011)

\section{Pengalaman Kerja}

Pengalaman kerja akan dapat berpengaruh terhadap kualitas audit yang dihasilkan, karena pengalaman akan diperoleh jika seorang auditor mengerjakan suatu yang berulangulang sehingga kesalahan yang akan terjadi akan berkurang.

Menurut SPAP (2011) dalam Ajeng (2016) Standar Umum Pertama PSA No.4 menyatakan bahwa seberapapun tinggi keahlian seseorang dalam bidang lain, termasuk dalam bidang bisnis dan keuangan, ia belum dapat dikatakan memenuhi syarat dalam standar auditing apabila ia tidak mempunyai pendidikan dan pengalaman yang memadai dalam bidang audit. pencapaian keahlian tersebut dimulai dengan pendidikan formalnya, namun harus diimbangi dengan pengalaman-pengalaman selanjutnya dalam praktik audit. Seorang auditor yang baru masuk dalam karir auditing harus memperoleh pengalaman profesionalnya dengan cara mendapatkan supervisi dan review atas pekerjaannya di lapangan dari atasannya yang lebih berpengalaman.

\section{Time Budget Pressure}

Auditor harus paham betul akan time budget agar tekanan yang auditor rasakan akan rendah karena pada dasarnya time budget pressure merupakan tekanan karena beban kerja tidak sesuai dengan waktu yang disediakan. Ketika seorang auditor menghadapi time budget pressure dalam dirinya, auditor akan memberikan respon dengan dua cara, yaitu respon yang fungsional dan respon disfungsional (De Zoort dan Lord, 1997) dalam Susmiyanti (2016). Respon fungsional yaitu dimana perilaku auditor untuk bekerja lebih baik, dan menggunakan waktu dengan sebaik-baiknya dalam penyelesaian tugas auditnya. Sedangkan respon disfungsional yaitu perilaku negatif auditor yang akan memberikan dampak pada penurunan kualitas audit

\section{Kualitas Audit}

Menurut Walkins dalam (Mathius, 2016:79) "kualitas audit adalah seberapa sesuai audit dengan standar audit”.

Menurut Mathius (2016:80) "Kualitas audit merupakan probabilitas seorang auditor dalam menemukan dan melaporkan suatu kekeliruan atau penyelewengan yang terjadi dalam suatu sistem akuntansi klien". 
De Angelo (1981) dalam susmiyanti (2016), mendefinisikan "kualitas audit sebagai probabilitas dimana seorang auditor menemukan dan melaporkan tentang adanya suatu pelanggaran dalam sistem akuntansi kliennya".

\section{METODE PENELITIAN}

\section{Jenis Penelitian dan Populasi}

Jenis penelitian yang digunakan adalah Penelitian Kausal (Causal Research) yang merupakan metode penelitian untuk mengidentifikasi hubungan sebab-akibat (Jusuf Soewadji, 2012). Populasi penelitian ini adalah auditor yang berkerja pada Kantor Akuntan Publik di wilayah Jakarta Selatan yang diperoleh dari Direktori KAP yang dikeluarkan IAI.

\section{Teknik Pengambilan sampel}

Kriteria pengambilan sampel dalam penelitian ini adalah Auditor yang bekerja di Kantor Akuntan Publik, mempunyai pengalaman mengaudit minimal 2 tahun dan minimal berpendidikan sarjana (S1). Teknik pengambilan sampel dalam penelitian ini diambil dengan menggunakan metode Purposive Sampling yaitu merupakan teknik pengambilan sampel yang didasarkan atas pertimbangan-pertimbangan tertentu dari peneliti.

\section{Teknik Pengumpulan Data}

Teknik pengumpulan data yang digunakan dalam penelitian ini adalah kuesioner yang langsung disebar oleh peneliti yang terdiri dari 21 pernyataan.

Variabel Penelitian dan Operasional Variabel

Variabel independen dalam penelitian ini adalah skeptisme professional, pengalaman kerja, dan time budget pressure, sedangkan untuk variael dependennya adalah kualitas audit.

Semua instrument menggunakan skala likert 5 skala nilai yaitu sangat tidak setuju (STS) dengan nilai 1, tidak setuju (TS) dengan nilai 2, kurang setuju (KS) dengan nilai 3, setuju (S) dengan nilai 4, dan sangat setuju (SS) dengan nilai 5.

Operasional variabel dalam penelitian ini adalah:

- Skeptisme Profesional menurut Arens dalam Adrian (2013) adalah Melaksanakan tugas dengan sikap tekun dan penuh hati-hati, Tidak mudah percaya dengan bukti audit yang telah disediakan, Selalu mempertanyakan dan melakukan evaluasi secara kritis terhadap bukti audit, dan Selalu mengumpulkan bukti audit yang detail dan cukup, sesuai dengan audit yang akan dilakukan.

- Pengalaman Kerja menurut Standar Auditing seksi 330.2, 2006) dalam Nurdin adalah Lamanya bekerja sebagai auditor, Semakin dapat mengetahui informasi, Semakin dapat mendeteksi kesalahan, Semakin mudah mencari penyebab kesalahan, Banyaknya tugas audit organisasi, dan Pengumpulan dan pemilihan bukti

- Time Budget Pressure menurut Nurlaely (2010) adalah Pemahaman tentang time budge, Tanggungjawab terhadap time budget, Penilaian kinerja dari atasan, dan Frekuensi revisi time budget.

- Kualitas Audit menurut Mathius (2016) adalah melaporkan semua kesalahan klien, komitmen dalam menyelesaikan audit, berpedoman pada prinsip akuntansi dan prinsip 
audit, tidak percaya begitu saja pada pernyataan klien, dan sikap hati-hati dalam pengambilan keputusan.

\section{Teknik Analisis Data}

Tahap analisis data yaitu dengan menghitung profil responden, uji kualitas data, uji asumsi klasik. Pengujian hipotesis dengan uji parsial dan Analisis regresi linear berganda.

\section{ANALISIS HASIL DAN PEMBAHASAN}

Adapun jumlah kuisioner yang disebarkan kepada 12 kantor akuntan publik yang ada di Jakarta Selatan adalah sebanyak 114 kuisioner dengan 108 kuisioner yang kembali dan 104 kuisioner yang dapat diolah. Setelah dilakukan Uji Realibilitas dan Validitas serta dilakukan Uji Asumsi Klasik dan Uji Korelasi. Selanjutnya dilakukan Uji t dan Analisis Regresi Linear Berganda untuk mengetahui masing-masing pengaruh antara variabel independen terhadap variabel dependen. Adapun hasilnya bisa dilihat dibawah ini

\section{Uji Hipotesis}

\section{Uji t ( Uji Parsial)}

\begin{tabular}{|c|c|c|c|c|c|c|}
\hline \multicolumn{7}{|c|}{ Coefficients $^{a}$} \\
\hline \multirow{2}{*}{\multicolumn{2}{|c|}{ Model }} & \multicolumn{2}{|c|}{ Unstandardized Coefficients } & $\begin{array}{l}\text { Standardized } \\
\text { Coefficients }\end{array}$ & \multirow[b]{2}{*}{$\mathrm{T}$} & \multirow[b]{2}{*}{ Sig. } \\
\hline & & $\mathrm{B}$ & Std. Error & Beta & & \\
\hline \multirow[t]{4}{*}{1} & (Constant) & 6.832 & 1.717 & & 3.979 & .000 \\
\hline & Skeptisme Profesional & .305 & .090 & .328 & 3.381 & .001 \\
\hline & Pengalaman Kerja & .288 & .075 & .374 & 3.828 & .000 \\
\hline & Time Budget Pressure & -.103 & .078 & -.100 & -1.315 & .192 \\
\hline
\end{tabular}

Berdasarkan Tabel di atas, maka dapat dijelaskan mengenai pengaruh secara parsial masing-masing variabel bebas sebagai berikut:

\section{Pengaruh Skeptisme Profesional (X1) Terhadap Kualitas Audit (Y)}

Berdasarkan tabel diatas terlihat bahwa $t_{\text {hitun }}>t_{\text {tabel }}$ yaitu 3,381 $>1,984$ sedangkan nilai signifikan yang dihasilkan lebih kecil dari alpha $(\alpha)$, yakni $\quad 0,001<0,05$. Hal ini berarti secara parsial Skeptisme Profesional berpengaruh terhadap Kualitas Audit.

\section{Pengaruh Pengalaman Kerja (X2) Terhadap Kualitas Audit}

Berdasarkan tabel 4.19 diatas terlihat bahwa $t_{\text {hitung }}>t_{\text {tabel }}$ yaitu $3.828>1,984$ sedangkan nilai signifikan yang dihasilkan lebih kecil dari alpha $(\alpha)$, yakni $\quad 0,000<0,05$. Hal ini berarti secara parsial Pengalaman Kerja berpengaruh terhadap Kualitas Audit. 


\section{Pengaruh Time Budget Pressure (X3) Terhadap Kualitas Audit (Y)}

Berdasarkan tabel 4.18 diatas terlihat bahwa $t_{\text {hitun }}<t_{\text {tabel }}$ yaitu $-1,315<1,984$ sedangkan nilai signifikan yang dihasilkan lebih besar dari alpha $(\alpha)$, yakni 0,192 $>0,05$. Hal ini berarti menunjukkan bahwa keputusan yang diambil adalah menolak $H_{1}$ dan menerima $H_{0}$, berarti secara parsial Time Budget Pressure tidak berpengaruh secara signifikan terhadap Kualitas Audit.

\section{Analisis Regresi Linier Berganda}

\begin{tabular}{|c|c|c|c|c|c|c|}
\hline \multicolumn{7}{|c|}{ Coefficients $^{a}$} \\
\hline \multirow{2}{*}{\multicolumn{2}{|c|}{ Model }} & \multicolumn{2}{|c|}{ Unstandardized Coefficients } & $\begin{array}{c}\text { Standardized } \\
\text { Coefficients }\end{array}$ & \multirow[b]{2}{*}{$\mathrm{T}$} & \multirow[b]{2}{*}{ Sig. } \\
\hline & & $\mathrm{B}$ & Std. Error & Beta & & \\
\hline \multirow[t]{4}{*}{1} & (Constant) & 6.832 & 1.717 & & 3.979 & .000 \\
\hline & Skeptisme Profesional & .305 & .090 & .328 & 3.381 & .001 \\
\hline & Pengalaman Kerja & .288 & .075 & .374 & 3.828 & .000 \\
\hline & Time Budget Pressure & -.103 & .078 & -.100 & -1.315 & .192 \\
\hline
\end{tabular}

Berdasarkan Tabel yang diperoleh dari koefisien regresi di atas, maka dapat dibuat suatu persamaan regresi linear berganda sebagai berikut :

$$
Y=6,832+0,305 X_{1}+0,288 X_{2}-0,103 X_{3}+€
$$

Persamaan regresi linear di atas dapat dijelaskan sebagai berikut :

a. Nilai a (konstanta) pada hasil pengujian di atas adalah sebesar 6,832 yang berarti bahwa jika variabel independen (Skeptisme Profesional, Pengalaman Kerja, dan Time Budget Pressure) konstan, maka Kualitas Audit akan mengalami kenaikan sebesar 6,832. Nilai konstanta sebesar 6,832 menunujukkan nilai murni dari variabel Kualitas Audit (dependen) tanpa dipengaruhi variabel independen.

b. Koefisien regresi Skeptisme Profesional adalah sebesar 0,305 dimana angka ini menujukkan bahwa setiap peningkatan variabel Skeptisme Profesional sebesar satu satuan, maka akan meningkatkan Kualitas Audit sebesar 0,305. Koefisien bernilai positif artinya terdapat hubungan positif antara Skeptisme Profesional. Semakin meningkat Skeptisme Profesional maka akan meningkatkan Kualitas Audit dan begitu juga sebaliknya.

c. Koefisien regresi Pengalaman Kerja adalah sebesar 0,288 dimana angka ini menujukkan bahwa setiap peningkatan variabel Pengalaman Kerja sebesar satu satuan, maka akan meningkatkan Kualitas Audit sebesar 0,288. Koefisien bernilai positif artinya terdapat hubungan positif Pengalaman Kerja. Semakin meningkat Pengalaman Kerja, maka akan meningkatkan Kualitas Audit dan begitu juga sebaliknya

d. Koefisien regresi Time Budget Pressure adalah sebesar -0,103 dimana angka ini menujukkan bahwa setiap peningkatan variabel Time Budget Pressure sebesar satu satuan, maka akan meningkatkan Kualitas Audit sebesar -0,103. Koefisien bernilai negatif artinya terdapat hubungan negatif antara Time Budget Pressure. Semakin meningkat Time Budget Pressure, maka Kualitas Audit akan menurun dan begitu juga sebaliknya. 
Interprestasi Hasil Penelitian

Skeptisme Profesional (X1) Berpengaruh Positif dan Signifikan Terhadap Kualitas Audit

Hasil penelitian menunjukkan bahwa Skeptisme Profesional memiliki pengaruh positif dan signifikan terhadap Kualitas Audit. Sikap skeptisme professional merupakan evaluasi terhadap bukti-bukti audit serta tidak mudah percaya terhadap pernyataan klien sehingga auditor akan dapat menemukan pelanggaran - pelanggaran yang telah dilakukan pada laporan keuangan klien. De Angelo (1981) dalam Ningsih dan Dyan (2013) mendefenisikan kualitas audit sebagai suatu kondisi dimana auditor akan menemukan dan melaporkan pelanggaran dalam sistem akuntansi klien. Hasil ini sejalan dengan penelitian yang dilakukan oleh Ananda (2014) skeptisme profesional berpengaruh positif pada kualitas audit semakin tinggi skeptisme profesional maka akan semakin baik pula kualitas audit.

Skeptisme profesional sangat diperlukan untuk meningkatkan kualitas audit, karena dengan bersikap skeptis, auditor akan lebih berinisiatif untuk mencari informasi lebih lanjut dari manajemen mengenai keputusan-keputusan akuntansi yang diambil, dan menilai kinerjanya sendiri dalam menggali bukti-bukti audit yang mendukung keputusan-keputusan yang diambil oleh manajemen tersebut (Financial Reporting Council, 2010) dalam Djohar (2012).

Kesimpulan ini dibuktikan dengan hasil output SPSS dimana $t_{\text {hitun }}>t_{\text {tabel }}$ yaitu 3,381 > 1,984 sedangkan nilai signifikan yang dihasilkan lebih kecil dari alpha ( $\alpha$ ), yakni $0,001<0,05$. Hal ini berarti menunjukkan bahwa keputusan yang diambil adalah $H_{1}$ diterima dan $H_{0}$ ditolak, berarti secara parsial Skeptisme Profesional berpengaruh positif dan signifikan terhadap Kualitas Audit.

\section{Pengalaman Kerja (X2) Berpengaruh Positif dan Signifikan Terhadap Kualitas Audit}

Hasil penelitian ini menunjukkan bahwa Pengalaman Kerja berpengaruh Positif dan signifikan terhadap Kualitas Audit. Artinya semakin tinggi pengalaman seorang auditor maka semakin tinggi kulitas audit yang dihasilkannya. Pengalaman kerja diperoleh ketika seorang auditor mengerjakan sesuatu yang berulang-ulang sehingga auditor dapat mengetahui kesalahan yang terjadi dan auditor dapat menemukan penyebab kesalahan tersebut. Jika auditor dapat menemukan kesalahan dan penyebabnya maka kualitas audit yang dikerjakannya akan semakin baik. Hasil penelitian ini sejalan dengan penelitian yang dilakukan oleh Panggih (2015) yang menemukan hasil variabel pengalaman auditor berpengaruh signifikan pada kualitas audit

Menurut Jurnaedi (2014) Pengalaman kerja seseorang auditor akan menunjukkan jenis-jenis pekerjaan yang pernah dilakukan auditor tersebut dan memberikan peluang yang lebih besar bagi auditor tersebut untuk melakukan pekerjaan yang lebih baik, sehingga kualitas audit yang dilakukan akan semakin membaik. Selain itu dengan pengalaman yang dimiliki maka auditor akan lebih mudah mendeteksi kecurangan yang dilakukan oleh klien

Kesimpulan ini dibuktikan dengan melihat hasil output SPSS bahwa $t_{\text {hitu }}>$ $t_{\text {tabel }}$ yaitu 3,828 $>1,984$ sedangkan nilai signifikan yang dihasilkan lebih kecil dari alpha $(\alpha)$, yakni $0,000<0,05$. Hal ini berarti menunjukkan bahwa keputusan yang diambil adalah 
$H_{1}$ diterima dan $H_{0}$ ditolak, berarti secara parsial Pengalaman Kerja berpengaruh Positif dan signifikan terhadap Kualitas Audit.

\section{Time Buget Pressure (X3) Tidak Berpengaruh Secara Signifikan Terhadap Kualitas Audit}

Hasil penelitian ini menunjukkan bahwa Time Budget Pressure tidak berpengaruh secara signifikan terhadap Kualitas Audit. Artinya, meskipun time budget tinggi hal itu tidak membuat kualitas akan menurun karena meskipun auditor mengalami tekanan anggaran waktu akan tetapi auditor harus menjalankan pekerjaannya sesuai dengan standar yang telah ditetapkan, selain itu auditor dengan pengalaman yang tinggi tidak akan tepengaruh dengan tekanan anggaran waktu. Hal itu terlihat pendidikan responden auditor adalah minimal S1 dan lama bekerja 2 tahun keatas. Selain itu ada kemungkinan bahwa meskipun auditor mengalami time budget pressure terdapat Supervisor yang akan mengkoreksi hasil perkerjaannya tersebut.

Hasil ini tidak sejalan dengan penelitian yang dilakukan oleh Ningsih (2013) dan Kurnia (2014) yang mengatakan bahwa Time Budget Pressure berpengaruh negatif terhadap Kualitas Audit artinya semakin tinggi atau sempit time budget pressure yang diberikan klien kepada auditor, dapat menyebabkan menurunnya kualitas audit yang akan dihasilkan. Penelitian ini juga berbeda dengen penelitian yang dilakukan oleh Jelista (2015) dan Arisinta (2013) yang mendapatkan hasil jika time budget pressure memiliki pengaruh positif dan juga signifikan pada kualitas audit. Penelitian tersebut menyatakan apabila semakin sempit time budget pressure yang diberikan klien kepada auditor dalam menyelesaikan tugas audit maka berdampak pada tingginya kualitas audit yang dihasilkan.

Namun hasil penelitian ini sejalan dengan penelitian yang dilakukan oleh Asbullah (2017) yang menyatakan bahwa Time budget pressure tidak berpengaruh terhadap Kualitas Audit. Menurut Asbullah (2017) ada kemungkinan para auditor yang bekerja di KAP beranggapan bahwa time budget pressure yang diberikan kepada auditor saat melaksanakan penugasan atau pemeriksaan audit tidak ada pengaruh terhadap kualitas audit. Meskipun diberikan tekanan anggaran waktu untuk menyelesaikan pemeriksaan para auditor yang bekerja pada KAP tersebut tetap berkomitmen dan menjaga integritasnya sebagai auditor yang profesional. Hal ini dapat diasumsikan bahwa auditor yang menjadi responden pada penelitian ini memahami pengalokasian atau pembagian waktu atas tugasnya dapat dilakukan dengan baik serta mampu mengatasi setiap tekanan anggaran waktu yang diberikan untuk menyelesaikan pekerjaan, sehingga tidak mengurangi integritas para auditor ketika melakukan penugasan dan hasil pemeriksaan tetap terjamin serta dapat diandalkan.

Dalam hal ini, auditor merupakan seorang yang profesional dan dapat dipercaya dalam melaksanakan pekerjaannya meskipun mengalami time budget pressure namun kualitas audit yang dihasilkannya harus baik. Kesimpulan ini dibuktikan dengan melihat hasil

output SPSS bahwa $t_{\text {hit }}<t_{\text {tabel }}$ yaitu $-1,315<1,984$ sedangkan nilai signifikan yang dihasilkan lebih besar dari alpha $(\alpha)$, yakni 0,192 >0,05. Hal ini berarti menunjukkan bahwa keputusan yang diambil adalah $H_{1}$ ditolak dan $H_{0}$ diterima, berarti secara parsial Time Budget Pressure tidak berpengaruh secara signifikan terhadap Kualitas Audit. 


\section{KESIMPULAN DAN SARAN}

\section{Kesimpulan}

Berdasarkan hasil penelitian ini mengenai tentang Skeptisme Profesional, Pengalaman Kerja, Time Budget Pressure terhadap Kualitas Audit yang dikumpulkan pada beberapa KAP di wilayah Jakarta Selatan, maka dapat ditarik kesimpulan sebagai berikut :

1. Skeptisme Profesional berpengaruh positif dan signifikan terhadap Kualitas Audit

2. Pengalaman Kerja berpengaruh positif dan signifikan terhadap Kualitas Audit

3. Time Budget Pressure tidak berpengaruh terhadap Kualitas Audit

\section{Saran}

Berdasarkan penjelasan hasil penelitian dan pembahasan serta simpulan dalam penelitian ini maka saran dalam penelitian ini adalah:

1. Untuk peneliti selanjutnya dapat menambah pengujian faktor-faktor yang mempengaruhi Kualitas Audit selain Skeptisme Profesional, Pengalaman Kerja, Dan Time Budget Pressure

2. Penelitian berikutnya diharapkan dapat menambah jumlah sampel dan mewakili masingmasing subsektor sehingga hasilnya mampu menggambarkan secara menyeluruh keadaan Kantor Akuntan Publik di Indonesia. Selain itu, peneliti juga dapat memperpanjang periode pengamatan yang akan diteliti. 


\section{DAFTAR PUSTAKA}

\section{Daftar buku:}

Arens, Alvin A., Elder, Beasley dan Jusuf. 2008. Auditing dan Jasa Assurance Pendekatan Terpadu. buku 1. Jakarta: Salemba Empat

Arens, Alvin A., Elder, Beasley dan Jusuf. 2011. Auditing dan Jasa Assurance Pendekatan Terpadu. buku 1. Jakarta: Salemba Empat

Agoes, Sukrisno. 2012. Auditing. Edisi ke-3. Jakarta: Lembaga Penerbit Fakultas Ekonomi Universitas Indonesia

Ghozali. 2012 Aplikasi Analisis Multivariate IBM SPSS 20. Semarang: Universitas Diponegoro.

Ikatan Akuntan Indonesia. 2011. Standar Profesional Akuntan Publik Per 31 Maret 2011. Salemba Empat. Jakarta.

Riduwan, \& Engkos, K. A. (2011). Cara Menggunakan dan Memaknai Analisis Jalur (Path Analysis). Cetakan Ketiga. Bandung: Alphabeta.

Soewadji, J. (2012). Pengantar Metodologi Penelitian. Jakarta: Mitra Wacana Media.

Sugiyono. (2015). Metode Penelitian Kuantitatif, Kualitatif, dan R\&D. Bandung: Alfabeta.

Sulistyo, J. (2002). 6 Hari Jago SPSS 17. Yogyakarta: Cakrawala..

Tuanakotta, Theodorus M. 2011. Berpikir Kritis dalam Auditing. Jakarta: Salemba Empat

\section{Daftar Jurnal:}

A.A P Ratih Cahaya Ningsih dan P. Dyan Y S. 2013. Pengaruh Kompetensi, Independensi, dan Time Budget Pressure Terhadap Kualitas Audit. E-Jurnal Akuntansi Universitas Udayana

Adrian, Arfin. 2013. Skeptisisme Profesional Audit, Etika, Pengalaman dan Keahlian Audit Terhadap Ketetapan Pemberian Opini Auditor. Studi Empiris pada BPK RI Perwakilan Provinsi Riau. Artikel Penelitian : Universitas Negeri Padang

Ahmad, Afridian Wirahadi, Fera Sriyuniati, Nurul Fauzi, dan Yosi Septriani. 2011. Pengaruh Kompetensi dan Independensi Pemeriksaan Terhadap Kualitas Hasil Pemeriksaan Dalam Pengawasan Keuangan Daerah: Studi Pada Inpektorat Kabupaten Pasaman. Jurnal Akuntansi dan Manajemen. 6 (2), hal: 63-73.

Ajeng, Citra Dewi. 2016. Pengaruh Pengalaman Kerja, Kompetensi, dan Independensi Terhadap Kualitas Audit dengan Etika Auditor Sebagai Variabel Moderasi. (Studi 
Empiris pada Auditor Internal Inspektorat Provinsi Daerah Istimewa Yogyakarta). Universitas Negri Yogyakarta

Ananda, Rahmatika. 2014. Pengaruh Skeptisme Profesional, Kepatuhan pada Kode Etik, dan independensi terhadap Kualitas Audit (Studi Empiris pada BPKP Perwakilan Sumatera Utara). Universitas Sumatera Utara.

Arisinta, Octaviana. 2013. Pengaruh Kompetensi, Independensi, Time Budget Pressure, Dan Audit Fee Terhadap Kualitas Audit Pada Kantor Akuntan Publik Di Surabaya. Jurnal Ekonomi dan Bisnis, Vol.23(3)

Badjuri, A. (2011). Faktor - Faktor yang Berpengaruh Terhadap Kualitas Audit Auditor Independen pada Kantor Akuntan Publik (KAP) di Jawa Tengah. Dinamika Keuangan dan Perbankan, III (2)

Bayu Pranadata, I,N,W dan I D N Badera. 2016. Pengaruh Kompetensi, Due Profesional Care, Pengalaman Kerja dan Besaran Fee Audit Pada Kualitas Audit. E-Jurnal Akuntansi. Universitas Udayana

Djohar, Randy Adisaputra. 2012. Faktor-Faktor Yang Berkontribusi Terhadap Skeptisme Profesional Auditor. Skripsi S1. Yogyakarta: Fakultas Ekonomi Universitas Atma Jaya

Hanjani, A. dan Rahardja. 2014. Pengaruh Etika Auditor, Pengalaman Auditor, Fee Audit, dan Motivasi Auditor Terhadap Kualitas Audit (Studi Pada KAP di Semarang). E-Journal Accounting

Hutabarat Goodman. 2012. Vol. 6 No. 1, Januari. "Pengaruh Pengalaman, Time Budget Pressure dan Etika Auditor terhadap Kualitas Audit.” Jurnal Ilmiah ESAI.

Iriyadi, dan Vannywati. 2011. Pengaruh Profesionalisme Auditor dan Etika Profesi auditor Terhadap Pertimbangan Tingkat Materialitas. Jurnal Ilmiah Ranggagading Vol 11 No 2.

Jelista,Mutiara. 2015. Pengaruh Kompleksitas Audit,Tekanan Anggaran Waktu, dan Pengalaman Auditor terhadap Kualitas Audit dengan Variabel Moderating Sistem Informasi. Jom FEKON. Vol. 2(2)

Leni Deli, Ade Fatma dan Firman Syarif. 2015. Faktor-Faktor Yang Mempengaruhi Kualitas Audit dengan Etika Auditor Sebagai Moderating Variabel. Jurnal Riset Akuntansi dan Bisnis. Universitas Sumatera Utara.

M.Nurdin. 2016. Pengaruh Pengendalian Internal, Independensi, pengalaman Keja, dan Kompetensi Auditor Terhadap Kualitas audit (Studi Kasus Pada Auditor Internal PT BANK BCA.Tbk di Jakarta). Skripsi. Universitas Mercu Buana

Marisa Fitria. 2016. Pengaruh Time Budget Pressure, Due Profesional Care dan Etika Auditor Terhadap Kualitas Audit DenganPerilaku Disfungsional Auditor Sebagai Moderator (Study Empiris Pada Kantor Akuntan Publik Di Pekanbaru Dan Medan) 
Nandari A,W,S dan Latrini M,Y. 2015. Pengaruh Sikap Skeptis, Independensi, Penerapan Kode Etik, dan Akuntabilitas Terhadap Kualitas Audit. ISSN : 2302-8578 E-jurnal Akuntansi Universitas Udayana 10.1 (2015)

Ni Komang, A, P, D \& I D G Dharma S. (2016) Pengaruh Akuntabilitas, Karakteristik Personal Auditor, dan Skeptisme Profesional Pada Kualitas Audit. E-Jurnal Akuntansi Universitas Udayana Vol.17.3 11

Ni Made, D Rossita \& I M Sukartha. (2017) Pengaruh Kompetensi, Komitmen Organisasi, Skeptisme Profesional dan Motivasi Terhadap Kualitas Audit. EJurnal Akuntansi Universitas Udayana Vol.20.3

Ningsih, Putu Ratih Cahaya dan P. Dyan Yaniartha. 2013. "Pengaruh Kompetensi, dan Time Budget Pressure Terhadap Kualitas Audit". EJurnal Akuntansi Universitas Udayana 4.1 ISSN 2302-8556. Halaman 92-109

Nurlaeli, Fenti. 2010. "Pengaruh Kompetensi, Independensi Dan Time BudgetPressure Terhadap Kualitas Audit (Studi Pada Auditor di BPKP Jawa Tengah)”. Semarang : Universitas Negeri Semarang

Panggih Hastama, Lutiari. 2015. Pengaruh Independensi, Pengalaman, Due Profesional Care, dan Akuntabilitas Terhadap Kualitas Audit (Studi Empiris Pada Kantor Akuntan Publik Daerah Istimewa Yogyakarta). Skripsi. Universitas Sanata Dharma Yogyakarta.

Pangestika, Widya, T. Taufik dan A. Silfi. 2014. Pengaruh Keahlian Profesional, Independensi, dan Tekanan Anggaran Waktu terhadap Pendeteksian Kecurangan Studi Empiris pada Badan Pemeriksa Keuangan Perwakilan Provinsi Riau. JOM FEKOM, 1 (2), 1-15.

Prasita, A., dan P. H. Adi. 2007. Pengaruh Kompleksitas Audit dan Tekanan Anggaran Waktu Terhadap Kualitas Audit dengan Moderasi Pemahaman Terhadap Sistem Informasi. Jurnal Ekonomi dan Bisnis.

Saripudin, Netty Herawaty dan Rahayu. 2012. Pengaruh Independensi, pengalaman, Due Profesional Care, dan Akuntabilitas Terhadap Kualitas Audit. e-Jurnal BINAR AKUNTANSI. Vol. 1 No. 1. Universitas Jambi

Sukriah, Ika, dkk. (2009). Jurnal. "Pengaruh Pengalaman Kerja, Independensi, Objektivitas, Integritas, dan Kompetensi terhadap Kualitas Hasil Pemeriksaan”. Simposium Nasional Akuntansi XII, Palembang. 
Susmiyanti. 2016. Pengaruh Fee Audit, Time Budget Pressure dan Kompleksitas Tugas Terhadap Kualitas Audit dengan Pengalaman Auditor Sebagai Variabel Moderating (Studi Empiris Pada Kantor Akuntan Publik di Yogyakarta).Skripsi. Universitas Negri Yogyakarta

Trisna, D dan I, D, Nyoman, B. 2017. Sistem Informasi Sebagai Pemoderasi Pengaruh Kompleksitas Audit dan Time Budget Presuure Terhadap Kualitas Audit.

Wini Triarini, D,A dan Yeni Latrini, N,M. 2016. Pengaruh Kompetensi Skeptisme Profesional, Motivasi dan Disiplin Terhadap Kualitas Audit. E-Jurnal Akuntansi Universitas Udayana

Yudha Permana P, I,G,K dan N P S Harta Mimba. 2017. Pengaruh Locus Of Control, Pengalaman Kerja, dan Time Budget Pressure Terhadap Kualitas Audit. E-Jurnal Akuntansi. Universitas Udayana 